\title{
Osmotin and Thaumatin from Grape: A Putative General Defense Mechanism Against Pathogenic Fungi
}

\author{
Sara Monteiro, Mahmoud Barakat, Maria A. Piçarra-Pereira, Artur R. Teixeira, and Ricardo B. Ferreira
}

First to fifth authors: Departamento de Botânica e Engenharia Biológica, Instituto Superior de Agronomia, Universidade Técnica de Lisboa, 1349-017 Lisboa, Portugal; first and fifth authors: Instituto de Tecnologia Química e Biológica, Universidade Nova de Lisboa, Apartado 127, 2781-901 Oeiras, Portugal; and third author: Escola Superior Agrária, Instituto Politécnico de Castelo Branco, 6001-909 Castelo Branco, Portugal.

Accepted for publication 3 July 2003.

\begin{abstract}
Monteiro, S., Barakat, M., Piçarra-Pereira, M. A., Teixeira, A. R., and Ferreira, R. B. 2003. Osmotin and thaumatin from grape: A putative general defense mechanism against pathogenic fungi. Phytopathology 93:1505-1512.

Little information is available concerning the expression of pathogenesis-related (PR) proteins in grapevine (Vitis vinifera) and their effect properties on the major fungal pathogens of grape. A systematic study was performed on the effect of total or individual grape proteins on mycelial growth, spore germination, and germ tube growth of Uncinula necator, Phomopsis viticola, and Botrytis cinerea. Two proteins, identi-

quencing as osmotin and thaumatin-like protein, exhibited strong antifungal activities in vitro, blocking the growth of Phomopsis viticola and Botrytis cinerea mycelia. In addition, they inhibited spore germination and germ tube growth of $U$. necator, Phomopsis viticola, and Botrytis cinerea. The presence of both proteins displayed a synergistic effect. The expression of osmotin and thaumatin-like protein was induced in grapevine leaves and berries infected with $U$. necator and Phomopsis viticola. Thaumatin previously was thought to occur exclusively in berries. Immunoblot analyses revealed the accumulation of the two PR proteins in infected leaves and berries, supporting a role in vivo in increasing the resistance of grapevine to fungal attack.
\end{abstract} fied as PR proteins by immunological methods and by N-terminal se-
Fungal pathogens are a major problem in the cultivation of grapes around the world. Fungal infection decreases yield and fruit quality through a reduction in plant vigor or by direct infection of the berries. Control is generally achieved by the application of fungicides. The economic costs and the negative impact associated with such applications led to a search for alternative strategies involving manipulation of host defense mechanisms.

Three major pathogens affect grapes worldwide: Uncinula necator (Sch.) Burrill and Plasmopara viticola (Berk. \& M.A. Curtis) Berl. \& De Toni in Sacc. are specific obligate biotrophic agents (that cause powdery mildew and downy mildew, respectively) and Botrytis cinerea Pers. is a nonspecific necrotrophic pathogen (that causes Botrytis gray mould). Among the diseases that affect grapevines, Phomopsis cane blight and leaf spot, caused by Phomopsis viticola (Sacc.) Sacc., and excoriosis, caused by Botryosphaeria dothidea (anamorphous Fusicoccum aesculi), are the most widespread. Unlike U. necator, Plasmopara viticola, and Botrytis cinerea, Phomopsis viticola and Botryosphaeria dothidea do not spread rapidly but they build up progressively in a vineyard, over a number of years, leading to a reduction in vigor and yield.

Plants respond to pathogen attack via the induction of various defense mechanisms. As described by Jacobs et al. (23), these include the deposition of mechanical barriers such as carbohydrates and hydroxyproline-rich glycoproteins within cell walls to limit invasion by fungal hyphae $(1,38)$, the synthesis of small secondary metabolites such as phytoalexins, which have been shown to be fungitoxic (19), and the production of active oxygen species within cells (4).

Corresponding author: R. B. Ferreira; E-mail address: ferreira@itqb.unl.pt

Publication no. P-2003-0926-02R

(C) 2003 The American Phytopathological Society
The response of plants to fungal attack also involves the induction of many defense-related proteins. In addition to resistance genes (R-genes) and genes encoding signal transduction proteins, they possess downstream defense genes, such as enzymes involved in the generation of phytoalexins, the enzymes of oxidative stress protection, tissue repair, and lignification, and small peptides with antimicrobial activity, such as thionins, defensins, and lipid transfer proteins $(3,5,16,30)$. A large group of pathogenesisrelated (PR) proteins has been shown to be rapidly and massively induced both locally around infection sites and systemically (25). The PR proteins encompass several different classes of structurally and functionally unrelated proteins that have been grouped into 11 protein families according to sequence similarities, although additional pathogen-induced proteins with potential antipathogenic action are described (16,39). Members of several of these families were demonstrated to have a damaging action on the structures of the parasite, thus exhibiting antifungal activity in in vitro bioassays and supporting a possible role for these proteins in plant defense $(25,30)$. These include PR-1 and PR-5 (thaumatin-like proteins and osmotins), which are thought to create transmembrane pores and therefore have been named permatins; PR-2 ( $\beta$-1,3-glucanases) and PR-3, 4, 8, and 11 (chitinases), which attack $\beta$-1,3-glucans and chitin, respectively, components of the cell walls in most higher fungi. Several reports demonstrated that transgenic plants overexpressing some PR genes show enhanced resistance to fungal pathogens $(18,22,24,32$, 42,45,46).

Little information is available concerning the expression of PR proteins in grapevines and on their antifungal activity on the major fungi that infect this plant. In this work, we report a systematic study on the effect of PR proteins on the mycelial growth and spore germination of U. necator, Phomopsis viticola, and Botrytis cinerea as well as on the expression of these proteins in leaves and berries infected with these fungi. 


\section{MATERIALS AND METHODS}

Plant material. Grapevines (Vitis vinifera L. cvs. Moscatel, D. Maria, and F. Pires) were grown under greenhouse conditions at $25 \pm 4^{\circ} \mathrm{C}$ with a photoperiod of $16 \mathrm{~h}$. When appropriate, the first fully expanded leaf on new shoots was harvested. Ripened 'Moscatel' grapes were harvested in 2000 in the Palmela region of Portugal. The white wine used was prepared from the single grape cv. Assario (13), and the aquatic, higher plant Lemna minor L. was grown as described previously (12). In vitro plantlets of $V$. vinifera cv. Touriga Nacional also were used. Establishment and stock shoot multiplication were performed according to the method of Carvallho et al. (7).

Fungal culture and inoculation conditions and antifungal bioassays. The strain of Botrytis cinerea used was isolated from berries of $V$. vinifera cv. Cabernet Sauvignon grown in a local vineyard (Instituto Superior de Agronomia [ISA], Lisboa, Portugal) and was maintained on potato dextrose agar (PDA, Difco Laboratories, Detroit) at $25^{\circ} \mathrm{C}$ with a 16 -h/8-h light/dark cycle. Fresh subcultures were prepared every 15 days. Two types of antiBotrytis assays were performed: (i) Mycelial growth-Agar disks containing fungal inocula were placed in the center of petri dishes containing PDA medium. The plates were incubated at $25^{\circ} \mathrm{C}$ for $48 \mathrm{~h}$. After the fungal colony diameter reached $1.5 \mathrm{~cm}$, four filter paper disks were placed onto the medium around the edge of the colony. Native proteins, denatured proteins (incubated at $100^{\circ} \mathrm{C}$ for $4 \mathrm{~min}$ ), or water (control) were added to the paper disks. After incubation for $48 \mathrm{~h}$, the development of mycelium was taken as a measure of growth. (ii) Spore germination-All assays were performed under sterile conditions. Inoculum for spore germination was prepared by scraping plates and suspending conidia in $10 \mathrm{ml}$ of Ringer solution 1/4-strength (Oxoid Ltd., Basingstoke, England). The spore suspension was filtered through sterile Kimwipes to remove hyphal fragments, vortexed for $1.5 \mathrm{~min}$, and adjusted to $5 \times 10^{4}$ conidia per $\mathrm{ml}$ with the improved Neubauer hemacytometer chamber (Brand, Germany). Equal volumes of spore suspension and protein test solution (in water) were mixed. The protein test solution was replaced with sterile distilled water in control samples. These mixtures were added to a petri dish and covered with a sterile microscope slide. For microscope examination, samples were removed after 22 to $28 \mathrm{~h}$. The percentage of conidia germinating was determined as the percent germination of 20 groups of 10 spores randomly selected on the microscope slide.

Phomopsis viticola was supplied by $\mathrm{H}$. Oliveira and C. Rego (ISA). The procedures utilized for mycelial growth and spore germination in the anti-Phomopsis assays were identical to those described above with the following exceptions: (i) the strain of Phomopsis viticola used was isolated from $V$. vinifera cv. Tinta Roriz; (ii) fresh subcultures were prepared every month; (iii) in the mycelial growth assay, the proteins were added to the paper disks in the petri dishes 10 to 15 days after the inoculation; and (iv) in the spore germination assay, no filtration was performed because the Phomopsis viticola spores are separated from the fungus vegetative structures; furthermore, for microscope examination, samples were removed after 48 to $72 \mathrm{~h}$.

$U$. necator infections were maintained on grapevines under greenhouse conditions. The anti-Uncinula bioassays were performed according to the method described by Giannakis et al. (17) with some modifications. U. necator conidia were collected from leaves of plants growing in the greenhouse that were infected for 2 to 3 weeks. When appropriate, pure, native, or denatured proteins (or water in the controls) were mixed with $0.6 \%$ (wt/vol) agar precooled to $40^{\circ} \mathrm{C}$ and poured into $50-\mathrm{mm}$ diameter sterile petri dishes. The conidia were gently brushed onto the $0.6 \%$ (wt/vol) agar with a sterile brush. The dishes were then covered and incubated in the dark at $25^{\circ} \mathrm{C}$. After 1 to 2 days, germ tube extension was monitored, i.e., the extent of germination of the conidia was determined under a light microscope.
No bacterial or fungal contamination was observed during the incubation period.

Isolation of the total soluble protein from L. minor, Assario wine, grapevine leaves, and grape berries. Lemna fronds were frozen in liquid nitrogen and ground to a fine powder, and the total soluble protein was extracted in $100 \mathrm{mM}$ Tris- $\mathrm{HCl}$ buffer, $\mathrm{pH} 7.5$, containing $1 \mathrm{mM}$ phenylmethylsulfonylfluoride (PMSF). The homogenate was filtered through two layers of cheesecloth and centrifuged at $40,000 \times g$ for $10 \mathrm{~min}$ at $2^{\circ} \mathrm{C}$, and the supernatant was desalted at $2^{\circ} \mathrm{C}$ on a PD-10 column (Amersham Biosciences) previously equilibrated with $20 \mathrm{mM}$ Tris- $\mathrm{HCl}$ buffer, $\mathrm{pH} 7.5$.

Purification of the total soluble protein from Assario wine was performed essentially as described previously (28). Wine aliquots were thawed and centrifuged at $15,000 \times g$ for $5 \mathrm{~min}$, and the supernatant was desalted at $4^{\circ} \mathrm{C}$ in prepacked PD-10 Sephadex G25M columns (Amersham Biosciences) previously equilibrated with deionized water (Milli-Q Plus; Millipore, Bedford, MA). The protein samples were subsequently lyophilized (Edwards Micro Modulyo freeze-drier, Crawley, Sussex, UK), and the dried residue was solubilized in $20 \mathrm{mM}$ citrate- $\mathrm{NaOH}$ buffer, $\mathrm{pH}$ 2.5. The sample containing the wine total soluble protein was subsequently purified by fast protein liquid chromatography (FPLC) cation exchange chromatography on a Mono S HR5/5 column (Pharmacia LKB) previously equilibrated in $20 \mathrm{mM}$ citrate- $\mathrm{NaOH}$ buffer, $\mathrm{pH}$ 2.5. The bound proteins were eluted with a step gradient ( 0 to $1 \mathrm{M})$ of $\mathrm{NaCl}$.

Isolation of the total protein from grapevine leaves. Young leaves $(500 \mathrm{mg})$ were ground to a fine powder under liquid nitrogen and homogenized in $5 \mathrm{ml}$ of $100 \mathrm{mM}$ phosphate buffer, pH 8.0, containing $1 \mathrm{mM}$ PMSF and $250 \mathrm{mg}$ of polyvinylpyrrolidone (PVP). The homogenate was filtered through two layers of cheesecloth and centrifuged at $15,000 \times g$ for $10 \mathrm{~min}$ at $4^{\circ} \mathrm{C}$. The supernatant was desalted at $4^{\circ} \mathrm{C}$ on a $\mathrm{PD}-10$ column previously equilibrated with $20 \mathrm{mM}$ phosphate buffer, $\mathrm{pH}$ 8.0.

The grape proteins were extracted following a modification of a methodology suitable to extract proteins from plant tissues rich in phenolic compounds (31). The pulp from mature berries $(100 \mathrm{~g})$ was ground to a fine powder under liquid nitrogen and homogenized in $250 \mathrm{ml}$ of ice cold $250 \mathrm{mM}$ HEPES [ $N$-2-hydroxyethylpiperazine- $N^{\prime}$-2-ethanesulfonic acid]/200 mM Tris buffer, $\mathrm{pH}$ 7.7, containing $10 \mathrm{mM} \mathrm{NaHCO} 3,10 \mathrm{mM} \mathrm{MgCl}, 0.1 \mathrm{mM}$ EDTA, $10 \mathrm{mM}$ 2-mercaptoethanol, $10 \mathrm{mM}$ sodium diethyldithiocarbamate, $0.1 \%$ (vol/vol) Tween 80 , and $6 \mathrm{~g}$ of PVP. The solution was mixed in a blender and centrifuged at $10,000 \times g$ for $40 \mathrm{~min}$ at $4^{\circ} \mathrm{C}$. The supernatant was passed through filter paper, desalted on a PD-10 column pre-equilibrated with water ( $\mathrm{pH}$ adjusted with $10 \mathrm{mM} \mathrm{NaOH}$ to 7.5), frozen, and lyophilized. The dried residue was resuspended and solubilized in $20 \mathrm{mM}$ citrate- $\mathrm{NaOH}$ buffer, pH 2.5.

Fractionation of the total soluble protein from wine and grape berries by FPLC ion exchange chromatography. Selected wine polypeptides were purified by a combination of FPLC cation/anion exchange chromatography. A sample containing the wine total soluble proteins was fractionated by FPLC cation exchange chromatography on a Mono S HR5/5 column previously equilibrated in $20 \mathrm{mM}$ citrate- $\mathrm{NaOH}$ buffer, $\mathrm{pH} 2.5$. The bound proteins were eluted with a continuous gradient $(0$ to $1 \mathrm{M})$ of $\mathrm{NaCl}$. Each of the peaks obtained with the continuous gradient was subsequently desalted in PD-10 Sephadex G-25M columns previously equilibrated with water, lyophilized, dissolved in $20 \mathrm{mM}$ piperazine buffer, $\mathrm{pH} 9.8$, and fractionated by FPLC anion exchange chromatography on a Mono Q HR5/5 column (Pharmacia LKB) previously equilibrated in the same buffer. The bound proteins were eluted with a continuous gradient $(0$ to $1 \mathrm{M})$ of $\mathrm{NaCl}$.

A $20-\mathrm{kDa}$ Assario polypeptide was purified for the production of specific polyclonal antibodies as described previously (29). The total Assario wine proteins were fractionated by FPLC cation ex- 
change chromatography on the Mono S. The 20-kDa polypeptide was further purified by preparative sodium dodecyl sulfate-polyacrylamide gel electrophoresis (SDS-PAGE).

The extract containing the total soluble proteins from grape berries was clarified by passage through a carboxymethyl (CM) cellulose column previously equilibrated in $20 \mathrm{mM}$ citrate- $\mathrm{NaOH}$ buffer, $\mathrm{pH}$ 2.5. At this $\mathrm{pH}$, polysaccharides and other neutral or negatively charged high-molecular-mass compounds do not bind to the gel but pass through the column. Total proteins, positively charged at $\mathrm{pH} 2.5$, are retained by the gel and are eluted with $1 \mathrm{M}$ $\mathrm{NaCl}$ (29). The fraction containing the total soluble protein was subsequently dialyzed in $20 \mathrm{mM}$ citrate- $\mathrm{NaOH}$ buffer, $\mathrm{pH} 2.5$, and loaded into the FPLC cation exchange Mono S column previously equilibrated in the same buffer. The bound proteins were eluted with a continuous gradient $(0$ to $1 \mathrm{M})$ of $\mathrm{NaCl}$.

Electrophoresis, western blotting, and immunoblotting. SDSPAGE was performed according to a modification (9) of the methods described by Weber and Osborn (44) and Laemmli (26). The modification included the use of $m$-cresol purple as the tracking dye and the inclusion of $0.1 \mathrm{M}$ sodium acetate in the anode buffer to allow the resolution of polypeptides with molecular masses ranging from 2.5 to $>200 \mathrm{kDa}$. The molecular mass polypeptide standards used ranged from the 205-kDa subunit of rabbit muscle myosin to the $14.2 \mathrm{kDa}$ of bovine milk $\alpha$-lactalbumin.

Western blotting was performed with a semidry electrophoretic transfer cell (Trans-blot SD; Bio-Rad, Richmond, CA) as described previously (29). After protein transfer, the proteins were immobilized on nitrocellulose membranes (40), visualized by incubation in an amido black 10B/methanol/acetic acid solution, and destained in 2-propanol/acetic acid. The blots destined for immunoblotting were processed as described previously (15). Tween 20 and nonfat dried milk were included in the antibody-containing solutions. Tween 20 with a concentration of $0.05 \%$, vol $/ \mathrm{vol}$, was used to reduce nonspecific binding and nonfat dried milk was used as a blocking agent to saturate the remaining protein binding sites.

Production of antibodies and preparation of antisera. Antibodies against Assario wine proteins were produced as described previously (29). Briefly, New Zealand female rabbits were immunized with purified antigen $(400 \mu \mathrm{g}$ of the $20-\mathrm{kDa}$ Assario polypeptide) in complete Freund's adjuvant. To obtain a high titer, three booster injections of $400 \mu \mathrm{g}$ of antigen were given every 2 weeks in complete Freund's diluted 1:10 with incomplete adjuvant. Total blood was taken from the heart 12 days after the third booster injection. Blood samples were allowed to clot, and the serum was collected, centrifuged, and stored at $-70^{\circ} \mathrm{C}$.

General assays. Protein content was measured according to a modification of the Lowry method (2). Total polysaccharides also were determined $(35,37)$.

Polypeptide sequencing. All the solutions used in the gels and the electrophoresis buffers were freshly prepared and filtered (Whatman 3MM). The SDS used was either ultra pure or twice recrystallized from ethanol and water (21). To prevent blockage of the amino terminals of the polypeptides, the gels were subjected to a pre-electrophoresis $(30 \mathrm{~min}$ at $200 \mathrm{~V})$ in $350 \mu \mathrm{l}$ of $10 \mathrm{mM}$ glutathione per $70 \mathrm{ml}$ of the upper buffer (to avoid degradation of tryptophan and methionine residues). Electrophoresis was then performed by adding $70 \mu \mathrm{l}$ of $100 \mathrm{mM}$ thioglycolic acid to $70 \mathrm{ml}$ of the upper buffer (Applied Biosystems, Foster City, CA) according to manufacturer's instructions. These precautions are meant to remove charged impurities and noncharged reactive species such as acrylamide monomers and other reactive substances and to reduce peroxides and residual radicals (8). The membrane used for electroblotting (20) was a ProBlot polyvinylidene difluoride polymer (PVDF) from Applied Biosystems. The buffer used for electroblotting was a $10 \mathrm{mM}$ solution of 3-[cycloheximide]-1propane-sulfonic acid (CAPS) in 10\% (vol/vol) methanol (27). Electroblotting was performed for $1.25 \mathrm{~h}$ at $15 \mathrm{~V}$ and $4^{\circ} \mathrm{C}$ in a TransBlot semidry transfer cell (Bio-Rad). The membranes were stained with Ponceau S (Applied Biosystems) according to the manufacturer's instructions. The polypeptides immobilized on the membranes were sequenced (Edman degradation) on a protein sequencer (Perkin-Elmer Applied Biosystems, Model 477A) online associated with a high-performance liquid chromatography analyzer (Model 120A).

\section{RESULTS}

Specificity of the polyclonal antibodies for the grape PR proteins. Polyclonal antibodies were developed in rabbits against a highly purified 20-kDa polypeptide extracted from Assario wine as described previously (29). To assess the degree of specificity of the antibodies produced against the major 20-kDa Assario wine polypeptide, L. minor was used as a control, not only because this aquatic, higher plant contains a very wide range of different polypeptides but also because two of them, the large $(52 \mathrm{kDa})$ and small $(14.5 \mathrm{kDa})$ subunits of the photosynthetic enzyme ribulose bisphosphate carboxylase, are extremely abundant (15). The antibodies were highly specific for the Assario polypeptide (Fig. 1). The SDS gel presented (Fig. 1A) shows the total polypeptide pattern of both $L$. minor cells and the Assario wine. When the proteins present in the gel were transferred onto a nitrocellulose membrane and the resulting blot stained with amido black (data not shown), it was observed that the transfer process had been highly efficient. When a similar blot was processed and probed with the anti-20-kDa Assario polypeptide antibodies (Fig. 1B), no signal was produced with the Lemna proteins, despite the ex-

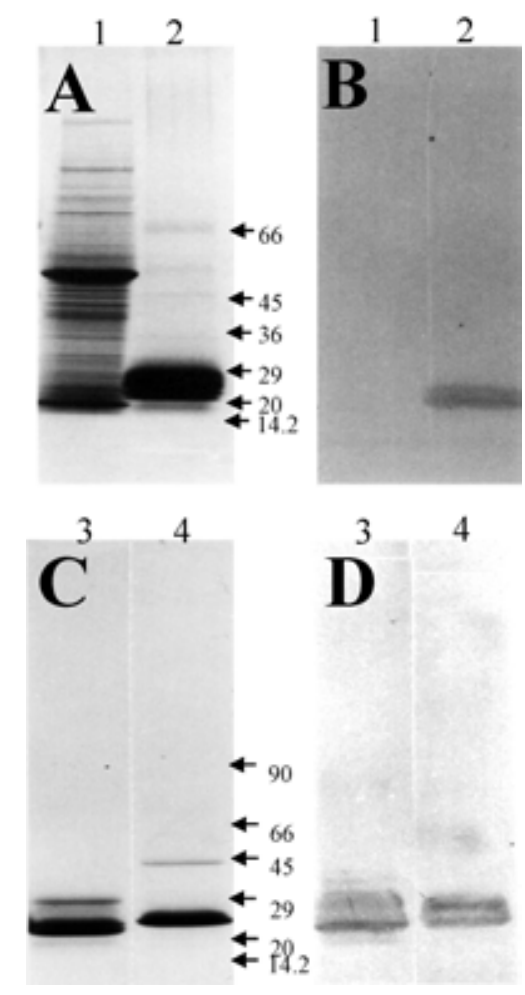

Fig. 1. Characterization of the anti-pathogenesis-related proteins antibodies. $\mathbf{A}$ and B, Specificity of the antibodies. Lemna minor total soluble protein (lane $1,80 \mu \mathrm{g}$ of protein in $\mathbf{A}$ or $20 \mu \mathrm{g}$ in $\mathbf{B}$ ) or the total Assario wine protein (lane 2, $80 \mu \mathrm{g}$ of protein in $\mathbf{A}$ or $25 \mu \mathrm{g}$ in $\mathbf{B}$ ) were subjected to sodium dodecyl sulfate-polyacrylamide gel electrophoresis (SDS-PAGE) and A, the total polypeptides stained with Coomassie Brilliant Blue $\mathrm{R}$ or $\mathbf{B}$, transferred onto a nitrocellulose membrane and subjected to immunoblotting and probed with the anti-wine polypeptide antibodies. $\mathbf{C}$ and $\mathbf{D}$, Identification of the polypeptides recognized by the antibodies. Selected wine polypeptides (lanes 3 and $4,100 \mu \mathrm{g}$ of protein in $\mathbf{C}$ or $50 \mu \mathrm{g}$ in $\mathbf{D}$ ) were purified by a combination of fast protein liquid chromatography cation/anion exchange, subjected to SDS-PAGE, and either $\mathbf{C}$, stained for total protein or $\mathbf{D}$, probed with the antibodies. Molecular masses of markers are indicated in kilodaltons. 
tremely large number and abundance of proteins (Fig. 1A, lane 1). This result clearly indicates that these antibodies are highly specific.

In a subsequent experiment, two abundant polypeptides from Assario wine were selected and subsequently purified by a combination of FPLC cation and anion exchange chromatographies. These polypeptides (Fig. 1C) are recognized by the anti-20-kDa Assario polypeptide antibodies (Fig. 1D) and were identified by $\mathrm{N}$-terminal sequencing as grape osmotin (Fig. 1C and D, lane 3) and grape thaumatin-like protein (Fig. 1C and D, lane 4; Table 1).

In fact, the anti-20-kDa Assario polypeptide antibodies specifically recognized a very wide diversity of structurally similar proteins that were present in grapes and wines, prepared from white or red cultivars, regardless of the cultivar, year, or region (13). This wide diversity of structurally similar proteins, or protein isoforms, explains the multiple bands visible on the western blot in Figure 1D (28). N-terminal sequencing analyses revealed that these are PR proteins with high sequence homologies with osmotin, thaumatin-like protein, and chitinase (28).

Effect of total or purified grape proteins on the mycelial growth of Botrytis cinerea and Phomopsis viticola. The total soluble protein from mature berries (cv. Moscatel) was extracted, isolated, clarified by passage through a CM-cellulose column, and fractionated by cation exchange chromatography on the FPLC Mono S column. The bound proteins were eluted with a continuous gradient $(0$ to $1 \mathrm{M})$ of $\mathrm{NaCl}$ (Fig. 2A). Eight protein peaks were identified and their polypeptide composition was analyzed by SDS-PAGE (Fig. 2B). The grape total protein fraction, the fraction that did not bind to the CM-cellulose column (named the polysaccharidic fraction [29]), and each of the eight protein peaks eluted from the Mono S column (Fig. 2A) were transferred into deionized water (by desalting in PD-10 columns previously equilibrated in deionized water; $\mathrm{pH}$ adjusted with $10 \mathrm{mM} \mathrm{NaOH}$ to 7.5) and their effect on the mycelial growth of Botrytis cinerea was examined. To this end, the fungus was allowed to grow on petri dishes until the colony diameter reached $1.5 \mathrm{~cm}$. Four filter paper disks were placed on the medium around the edge of the colony, and native proteins (Fig. 3, positions a and b), water (Fig. 3, control; position c), or denatured proteins (Fig. 3, position d) were added to the paper disks ( $200 \mu \mathrm{g}$ per disk). The results presented in Figure 3 show the mycelial growth after $48 \mathrm{~h}$ of incubation and indicate that the grape total protein fraction (Fig. 3B) and protein peaks 3 (Fig. 3E) and 4 (Fig. 3F) strongly inhibit the mycelia growth of Botrytis cinerea.

An identical experiment was performed to study the effect of the same protein fractions on the mycelial growth of Phomopsis viticola. Difficulties arising from the typical, very slow growth of this fungus on petri dishes resulted in much longer incubation periods. Nevertheless, similar results were obtained to the ones depicted in Figure 3, indicating that the grape protein peaks 3 and 4 (Fig. 2A) exhibit antifungal properties, clearly blocking the growth of Botrytis cinerea and Phomopsis viticola mycelia. These proteins also are recognized by the anti-20-kDa Assario polypeptide antibodies, indicating that they are PR proteins (Table 1).

Bioassay for $U$. necator, Phomopsis viticola, and Botrytis cinerea-Effect of total or purified grape proteins on spore germination and germ tube growth. Spores of U. necator, Phomopsis viticola, and Botrytis cinerea were germinated in the presence of total or purified grape proteins as described previ- ously. The results obtained, presented in Figure 4, show that the total grape protein strongly inhibited spore germination and germ tube growth in all of the fungi examined. In a separate experiment, the total grape protein was fractionated and the individual protein peaks were collected (Fig. 2). Their effect on spore germination and germ tube growth of $U$. necator, Phomopsis viticola, and Botrytis cinerea was investigated, including the analysis of native protein, denatured protein, and water (control) (Fig. 5). One hundred micrograms of protein was used in each assay. Once again, a strong inhibitory effect was observed with the proteins present in peaks 3 and 4 . Furthermore, a synergistic effect was detected when both fractions were simultaneously present ( $50 \mu \mathrm{g}$ of protein from fraction 3 plus $50 \mu \mathrm{g}$ of protein from fraction 4 ). N-terminal sequencing of the major polypeptides present in fractions 3 and 4 indicated that they correspond to grape osmotin and thaumatin, respectively (Table 1). Their expected molecular masses confirm this observation (14).

In a specific experiment, the effect of the total grape protein, as well as of the individual (peak 3 or peak 4) and combined (peaks 3 and 4) purified polypeptide fractions, on the germination of $U$. necator spores was determined by counting the number of spores germinated in randomly selected groups of 10 spores. Twenty
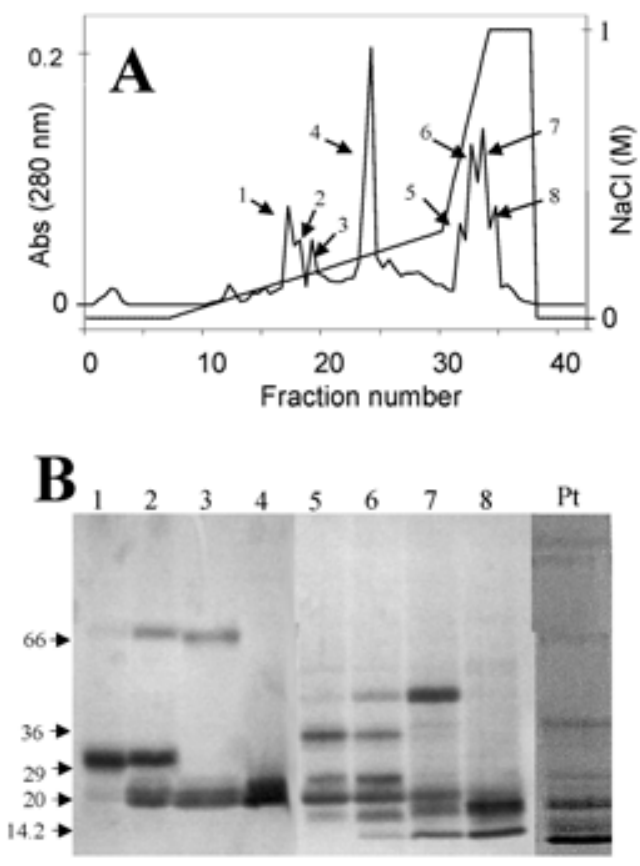

Fig. 2. Fractionation of the total soluble proteins from cv. Moscatel grapes by fast protein liquid chromatography (FPLC) cation exchange chromatography. The total soluble protein from mature 'Moscatel' grapes was extracted, isolated, clarified by passage through a carboxymethyl-cellulose column, and fractionated by FPLC cation exchange chromatography on a Mono S column previously equilibrated in $20 \mathrm{mM}$ citrate- $\mathrm{NaOH}$ buffer, $\mathrm{pH}$ 2.5. A, The bound proteins were eluted with a continuous gradient ( 0 to $1 \mathrm{M})$ of $\mathrm{NaCl}$. B, Fractions $(1 \mathrm{ml})$ were collected and analyzed by sodium dodecyl sulfate-polyacrylamide gel electrophoresis $(100 \mu \mathrm{g}$ of protein was loaded in each lane). Lanes 1 to 8 in $\mathbf{B}$ correspond to peaks 1 to 8 in $\mathbf{A}$. Lane Pt, grape total soluble protein. Molecular masses of standards are indicated in kilodaltons.

TABLE 1. N-terminal sequencing of the wine polypeptides presented in Figure 1C and D and comparison with the sequences of proteins from other sources ${ }^{\mathrm{a}}$

\begin{tabular}{|c|c|c|c|c|}
\hline Protein & Source & Alignment & Reference & Percent identity \\
\hline Figure $1 \mathrm{C}$ and $\mathrm{D}$, lane 3 & This work & ${ }^{1}$ ATFNIQNHHSYTVVAAAVPGGGMQL ${ }^{25}$ & - & - \\
\hline Osmotin-like protein precursor & Vitis vinifera (grape) & ${ }^{25}$ ATFNIQNHCSYTVWAAAVPGGGMQL ${ }^{49}$ & AN P93621 (TrEMBL) & 92.00 \\
\hline Figure $1 \mathrm{C}$ and $\mathrm{D}$, lane 4 & This work & ${ }^{1}$ ATFDILNKKTYTVVAAAA ${ }^{18}$ & - & - \\
\hline
\end{tabular}

a The database consulted was Swiss-Prot/TrEMBL (available online). 

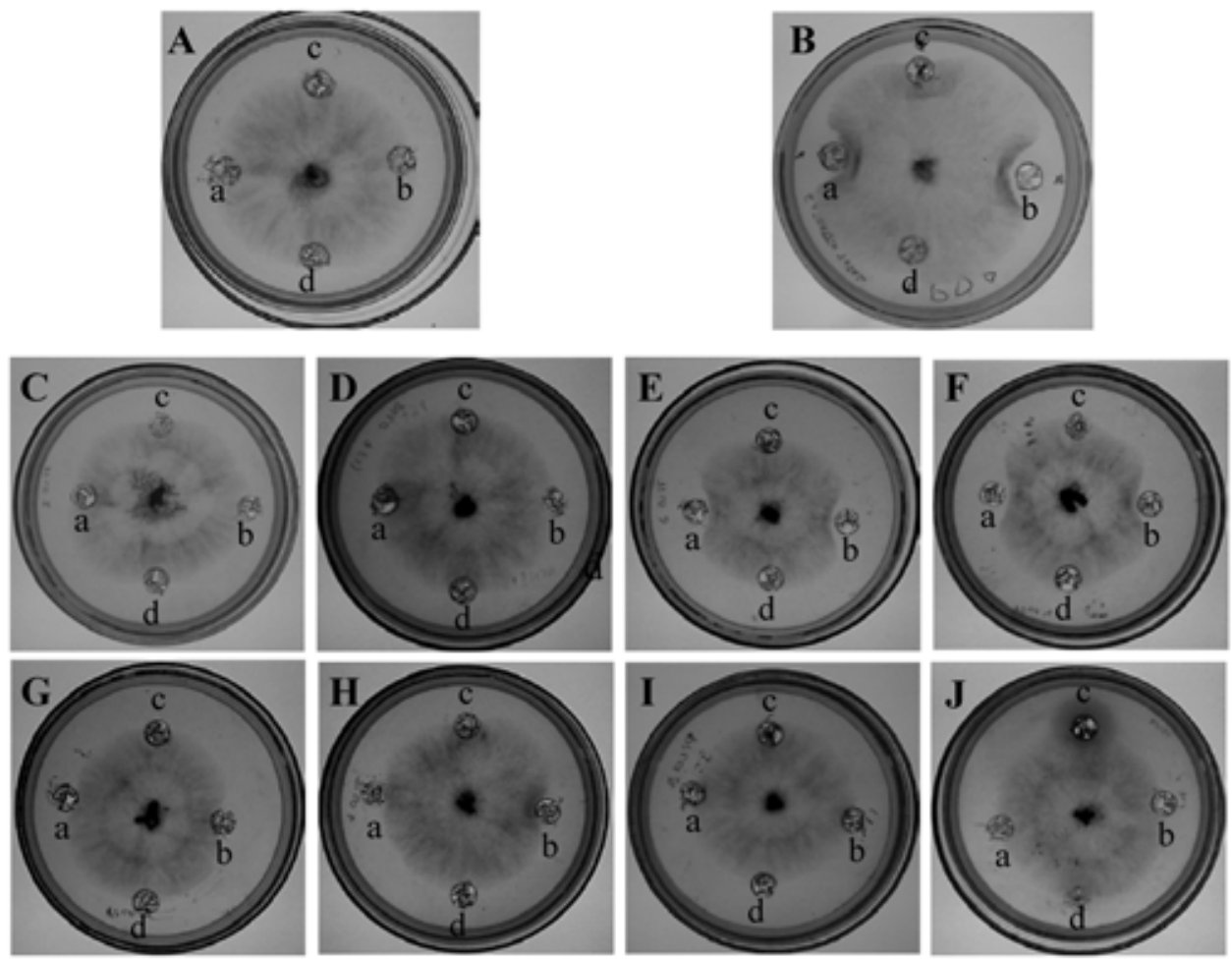

Fig. 3. Effect of total or purified grape proteins on the mycelial growth of Botrytis cinerea. The fungus was allowed to grow on petri dishes until the colony diameter reached $1.5 \mathrm{~cm}$. Four filter paper disks were placed onto the medium around the edge of the colony and native proteins (positions a and $\mathrm{b}$ ), water (control; position c), or denatured proteins (position d) were added to the paper disks (200 $\mu \mathrm{g}$ per disk). Photographs were taken after $48 \mathrm{~h}$ incubation. A, Polysaccharidic fraction; B, grape total soluble protein; $\mathbf{C}$ to J, Fractions obtained from the Mono S column (Fig. 2A) corresponding to peaks 1 to 8 , respectively.

A

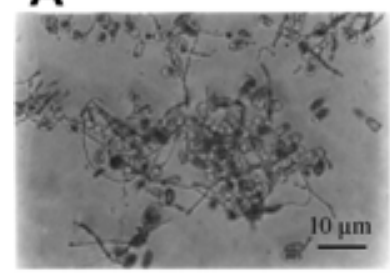

D

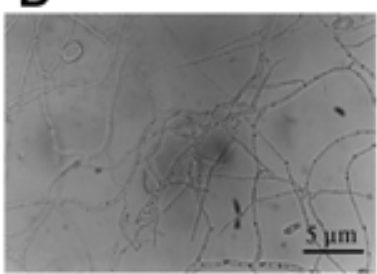

G

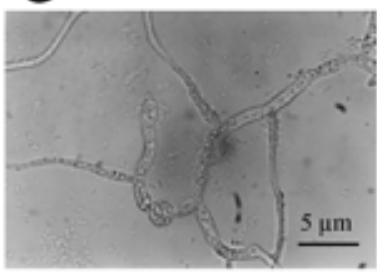

B

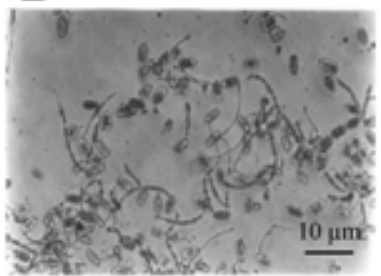

E

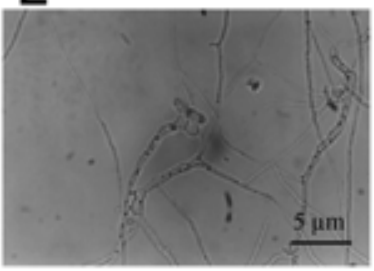

$\mathrm{H}$

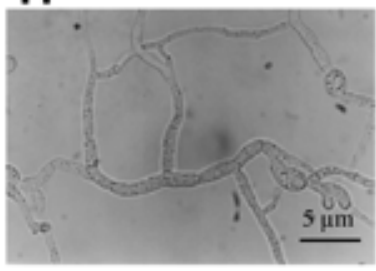

C

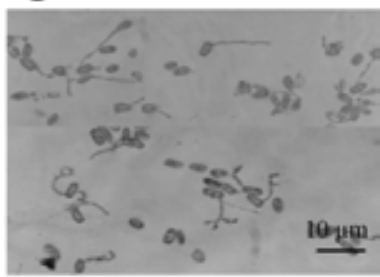

$\mathbf{F}$

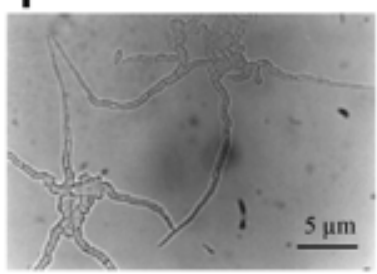

I

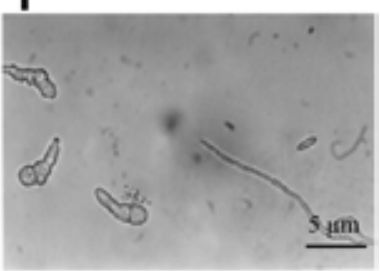

Fig. 4. Effect of total grape protein on spore germination and germ tube growth of Uncinula necator, Phomopsis viticola, and Botrytis cinerea. Spores of $\mathbf{A}$ to C, U. necator; $\mathbf{D}$ to $\mathbf{F}$, Phomopsis viticola; and $\mathbf{G}$ to I, Botrytis cinerea were germinated in the presence of A, D, and G, water (control); B, E, and $\mathbf{H}$, total denatured grape protein; or $\mathbf{C , ~ F}$, and I, total native protein. One hundred micrograms of protein was used in each assay. Observations were made by $\mathbf{A}$ to $\mathbf{C}$, phase contrast microscopy or by $\mathbf{D}$ to I, bright field. 
replicates were considered for each condition. The data obtained, presented in Table 2, clearly show the remarkable inhibitory effect of the total grape protein and of the proteins presents in peaks 3 and 4 on the germination of $U$. necator spores, as well as the synergistic effect detected when both protein fractions are present, confirming the results obtained earlier. It is important to note that these results simply reflect the countings obtained for germinated versus ungerminated spores. Therefore, the inhibitory effect of the total protein and of the individual or combined purified polypeptide fractions was grossly underestimated, because the length of the germinated germ tube was always smaller in the samples treated with native proteins than in the samples treated with water (control), as is evidenced in Figure 5A to D. Indeed, a statistical analysis $(n=10)$ performed for randomly selected germinating spores of $U$. necator revealed an average germ tube length of $64.60 \pm 4.87 \mu \mathrm{m}$ for the control (spores germinated in water; Fig. $5 \mathrm{~A}), 39.71 \pm 5.29 \mu \mathrm{m}$ for spores treated with the peak 3 protein (Fig. 5B), $29.26 \pm 1.72 \mu \mathrm{m}$ for spores treated with the peak 4 protein (Fig. 5C), and $15.97 \pm 2.31 \mu \mathrm{m}$ for spores treated with peaks 3 and 4 proteins (Fig. 5D). Once again, these observations fully confirm the results obtained previously.

Expression of $P R$ proteins in grapevine leaves and berries infected with $\boldsymbol{U}$. necator or Phomopsis viticola. The antifungal activities of grapevine osmotin and thaumatin detected in vitro toward U. necator, Phomopsis viticola, and Botrytis cinerea suggest that these proteins may play an important role in vivo in increasing the plant resistance to fungal attack. If that is the case, it seems likely that these proteins are overexpressed when grapevine leaves and berries are infected with pathogenic fungi. The results presented in Figure 6 show the accumulation of PR pro- teins in leaves (Fig. 6A) and berries (Fig. 6B) infected with $U$. necator and Phomopsis viticola. No osmotin and thaumatin were detected in healthy leaves (Fig. 6A, lane 1) and berries (Fig. 6B, lane 1). However, both of these proteins accumulated in leaves attacked with $U$. necator (Fig. 6A, lane 3) or with Phomopsis viticola (Fig. 6A, lane 4) and in berries infected with $U$. necator (Fig. $6 \mathrm{~B}$, lane 2). Interestingly, osmotin also accumulated in the leaves of healthy grapevine plants cultured in vitro (Fig. 6A, lane 2).

\section{DISCUSSION}

PR proteins constitute a major defense mechanism of plants against fungal pathogens. Not only do some of these proteins exhibit antifungal properties in vitro, but they have also been shown to be induced in vivo in a very large number of plants in response to fungal attack (43). Furthermore, overexpression of PR genes leads frequently to increases in host resistance (10).

Two studies have been reported on the in vitro antifungal activities of grapevine PR proteins. Chitinase and glucanase proteins purified from the leaves of a resistant grapevine cultivar inhibited the growth of $U$. necator in an in vitro bioassay (17). Grape chitinase and osmotin also inhibited mycelium growth of Botrytis cinerea (36). The data presented in Figures 3 to 5 and Table 2 clearly show that two proteins, identified as PR proteins by immunological methods and as osmotin and thaumatin-like protein by N-terminal sequencing and on the basis of their molecular masses, exhibit strong antifungal activity in vitro and display a synergistic effect when present simultaneously. They block the growth of Phomopsis viticola and Botrytis cinerea mycelia and exhibit a remarkable inhibitory action on spore germination and
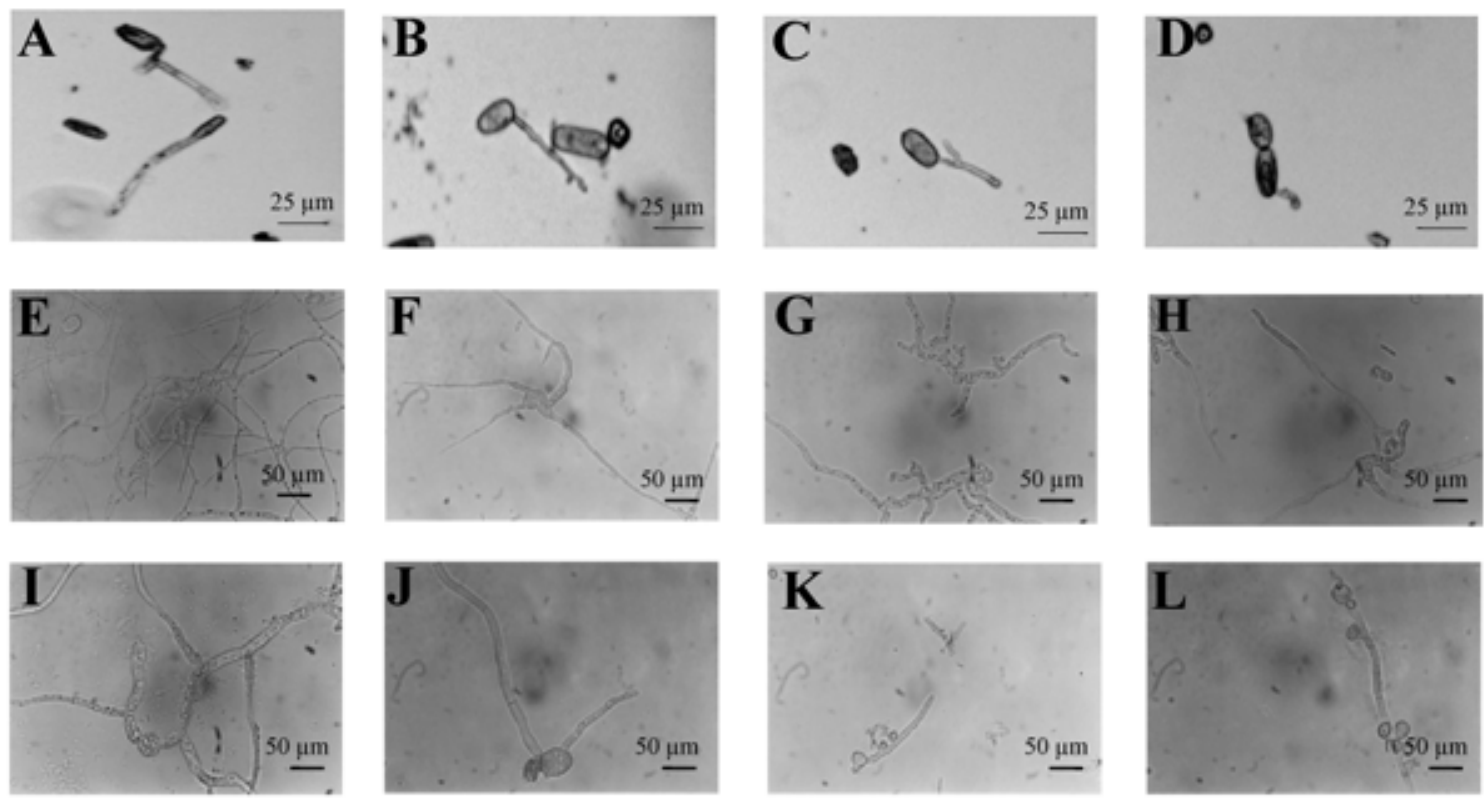

Fig. 5. Effects of the individual and combined purified polypeptide fractions on spore germination and germ tube growth of Uncinula necator, Phomopsis viticola, and Botrytis cinerea. Spores of A to D, U. necator; $\mathbf{E}$ to $\mathbf{H}$, Phomopsis viticola; and $\mathbf{I}$ to $\mathbf{L}$, Botrytis cinerea were germinated in the presence of $\mathbf{A}$, E, and I, water (control); $\mathbf{B}, \mathbf{F}$, and $\mathbf{J}$, protein from peak 3; C, G, and $\mathbf{K}$, protein from peak 4; or $\mathbf{D}, \mathbf{H}$, and $\mathbf{L}$, proteins from peaks 3 and 4 . A total of $100 \mu \mathrm{g}$ of protein (either single or combined fractions) was used in each assay. Observations were made by $\mathbf{A}$ to $\mathbf{D}$, phase contrast or by $\mathbf{E}$ to $\mathbf{L}$, bright field.

TABLE 2. Effect of total grape protein and of the individual and combined purified polypeptide fractions on the germination of Uncinula necator spores ${ }^{\mathrm{a}}$

\begin{tabular}{llcccrrrr}
\hline $\begin{array}{l}\text { Germination of } \\
\text { U. necator } \text { spores }\end{array}$ & Statistical analysis & Control & $\begin{array}{c}\text { Total denatured } \\
\text { grape protein }\end{array}$ & $\begin{array}{c}\text { Total native } \\
\text { grape protein }\end{array}$ & Peak 3 & Peak 4 & Peaks 3 and 4 \\
\hline Number of spores & Mean & 4.80 & 6.07 & 2.07 & 0.90 & 1.65 \\
germinated & Standard deviation & 2.30 & 2.25 & 1.32 & 1.16 & 0.60 \\
\hline
\end{tabular}

${ }^{\text {a }}$ Fungal spores were germinated in the presence of water (control), total denatured grape protein, total native grape protein, protein from peak 3 , protein from peak 4, or proteins from peaks 3 and 4 . One hundred micrograms of protein was used in each assay. The number of spores germinated in randomly selected groups of 10 spores was determined. Twenty replicates were considered for each condition. 
germ tube growth of $U$. necator, Phomopsis viticola, and Botrytis cinerea.

If grape osmotin and thaumatin do exhibit strong in vitro inhibitory effect on the mycelium growth and on spore germination and germ tube growth of the major fungi that attack grapevine, it is hypothesized that they fulfill an antifungal role in vivo as well. If this is true, it follows that an induction of these proteins is likely to occur in leaves and grapevines attacked with pathogenic fungi. Some information, although sparse, has already been published, particularly, regarding the activity levels of chitinases and $\beta$-1,3-glucanases. A ripening-related accumulation of PR proteins, a PR-4 chitinase (34) and a thaumatin-like protein (PR-5) (41), was reported in postveraison grapes after the onset of berry ripening. Induction in the activity of a number of PR proteins, including chitinase and $\beta$-1,3-glucanase, is observed in grapevine leaves following application of salicylic acid $(11,33)$. A positive correlation was detected between the combined activities of chitinase and $\beta$-1,3-glucanase of a range of grapevine cultivars and their observed field resistance to $U$. necator (17). Differential expression of two chitinase genes was recorded in grapevine responding to systemic acquired resistance activators and fungal challenge with Plasmopara viticola (6). A direct correlation was observed between the activities of chitinase and $\beta$-1,3-glucanase in the leaves and berries of susceptible grapevines and the severity of $U$. necator infection (23). Induction of chitinase and $\beta$-1,3-glucanase also was reported in grapevine leaves following infection by
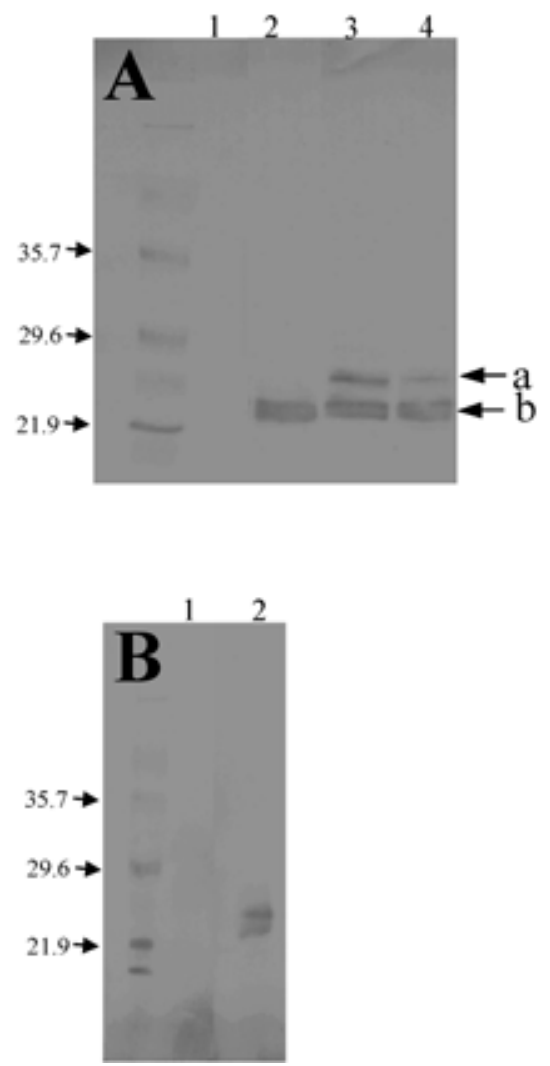

Fig. 6. Expression of pathogenesis-related proteins in grapevine leaves and berries infected with Uncinula necator or Phomopsis viticola. A, The total soluble proteins from the leaves of healthy grapevine plants (control; lane 1), healthy grapevine plants cultured in vitro (lane 2), plants infected with $U$. necator (lane 3), and plants infected with Phomopsis viticola (lane 4). B, The total soluble proteins from the berries of healthy grapevine plants (lane 1) and $U$. necator-infected plants (lane 2) were extracted, fractionated by sodium dodecyl sulfate-polyacrylamide gel electrophoresis, blotted onto a membrane, and probed with anti-wine polypeptide antibodies (Fig. 1; Table 1). Fifty micrograms of protein was loaded in each lane. Bands a and $b$, osmotin and thaumatin-like protein, respectively. Molecular masses of standards are indicated in kilodaltons.
Botrytis cinerea (33). Increased transcription of a chitinase (PR3 ), a glucanase (PR-2), and a thaumatin-like protein (PR-5) gene was noted to occur in $U$. necator-infected leaves and preveraison berries (23). Nevertheless, with the exception of Botrytis cinerea (33), to our knowledge, no data has demonstrated the increase in the translation of PR gene products in the leaves and berries of infected grapevines.

No osmotin or thaumatin-like protein was detected in healthy grapevine leaves or berries. However, immunoblot analysis revealed the accumulation of these proteins in both leaves infected with $U$. necator or Phomopsis viticola and in berries attacked with $U$. necator (Fig. 6). This is a surprising result because osmotin and thaumatin were previously thought to occur in the berries only, expressed in conjunction with the onset of sugar accumulation and berry softening $(14,41)$. Interestingly, osmotin also accumulates in healthy leaves of grapevine plants cultured in vitro, under aseptic conditions. This result was surprising and suggests that the plants propagated in vitro somehow sense a departure from optimal growing conditions. These results are in agreement with the accepted view that constitutive levels of PR proteins are typically absent in healthy plants, with the proteins being induced exclusively in response to wounding or to pathogen attack (43).

Given the physiological role attributed to PR proteins, genetically modified grapevines overexpressing the PR proteins would probably become more resistant to the attack of fungal pathogens. Indeed, the actual trend seems to be the overexpression of PR proteins in order to obtain plants with enhanced resistance to fungal attack. In the particular case of grapevine, a rice chitinase gene was recently introduced into the somatic embryos by Agrobacterium infection. Some of the transformants obtained exhibited increased resistance against powdery mildew caused by $U$. necator (45).

\section{ACKNOWLEDGMENTS}

Financial support for this work was provided by the Fundação para a Ciência e a Tecnologia, Lisboa, Portugal. We thank H. Oliveira and C. Rego (ISA, Lisboa, Portugal) for supplying Phomopsis viticola, A. Martins (ISA) for his help in keeping $U$. necator infections under greenhouse conditions, C. Silva (ISA) for maintaining fungi cultures, and M. Regala (ITQB, Oeiras, Portugal) for the $\mathrm{N}$-terminal sequencing experiments.

\section{LITERATURE CITED}

1. Aist, J. R. 1976. Papillae and related wound plugs of plant cells. Annu. Rev. Phytopathol. 14:145-163.

2. Bensadoun, A., and Weinstein, D. 1976. Assay of proteins in the presence of interfering materials. Anal. Biochem. 70:241-250.

3. Bergey, D. R., Howe, G. A., and Ryan, C. A. 1996. Polypeptide signaling for plant defensive genes exhibits analogies to defense signaling in animals. Proc. Natl. Acad. Sci. USA 93:12053-12058.

4. Brisson, L. F., Tenhaken, R., and Lamb, C. 1994. Function of oxidative cross-linking of cell wall structural proteins in plant disease resistance. Plant Cell 6:1703-1712.

5. Broekaert, W. F., Cammue, B. P. A., De Bolle, M. F. C., Thevissen, K., Desamblanx, G. W., and Osborn, R. W. 1997. Antimicrobial peptides from plants. Crit. Rev. Plant Sci. 16:297-323.

6. Busam, G., Kassemeyer, H., and Matern, U. 1997. Differential expression of chitinases in Vitis vinifera L. responding to systemic acquired resistance activators or fungal challenge. Plant Physiol. 115:1029-1038.

7. Carvallho, L., Santos, P., and Amâncio, S. 2002. Effects of light intensity and $\mathrm{CO}_{2}$ concentration during the acclimatization of in vitro grapevine. Vitis 41:1-6.

8. Choli, T., and Wittmann-Liebold, B. 1990. Protein blotting followed by microsequencing. Electrophoresis 11:562-568.

9. Christy, K. G., Latart, D. B., and Osterhoudt, W. 1989. Modifications for SDS-PAGE of proteins. BioTechniques 7:692-693.

10. Datta, K., Muthukrishnan, S., and Datta, S. K. 1999. Expression and function of PR-protein genes in transgenic plants. Pages 261-277 in: Pathogenesis-Related Proteins in Plants. S. K. Datta and S. Muthukrishnan, eds. CRC Press, Boca Raton, FL.

11. Derckel, J.-P., Audran, J.-C., Haye, B., Lambert, B., and Legendre, L. 1998. Characterization, induction by wounding and salicylic acid, and 
activity against Botrytis cinerea of chitinases and $\beta-1,3$-glucanases of ripening grape berries. Physiol. Plant 104:56-64.

12. Ferreira, R. B., and Davies, D. D. 1986. Is protein degradation correlated with either the charge or size of Lemna proteins? Planta 169:278-288.

13. Ferreira, R. B., Monteiro, S., Piçarra-Pereira, M. A., Tanganho, M. C., Loureiro, V. B., and Teixeira, A. R. 2000. Characterisation of the proteins from grapes and wines by immunological methods. Am. J. Enol. Vitic. 51:22-28.

14. Ferreira, R. B., Piçarra-Pereira, M. A., Monteiro, S., Loureiro, V. B., and Teixeira, A. R. 2002. The wine proteins. Trends Food Sci. Technol. 12:230-239.

15. Ferreira, R. B., and Shaw, N. M. 1989. Effect of osmotic stress on protein turnover in Lemna minor fronds. Planta 179:456-465.

16. Fritig, B., Heitz, T., and Legrand, M. 1998. Antimicrobial proteins in induced plant defence. Curr. Opin. Immunol. 10:16-22.

17. Giannakis, C., Bucheli, C. S., Skene, K. G. M., Robinson, S. P., and Scott, N. S. 1998. Chitinase and $\beta$-1,3-glucanase in grapevine leaves: A possible defence against powdery mildew infection. Aust. J. Grape Wine Res. 4:14-22.

18. Grison, R., Grezesbesset, B., Schneider, M., Lucante, N., Olsen, N., Leguay, J. J., and Toppan, A. 1996. Field tolerance to fungal pathogens of Brassica napus constitutively expressing a chimeric chitinase gene. Nat. Biotechnol. 14:643-646.

19. Hain, R., Reif, H., Krause, E., Langebartels, R., Kindl, H., Vornam, B., Wiese, W., Schmelzer, E., Schreier, P. H., Stöcker, R. H., and Stenzel, K. 1993. Disease resistance results from foreign phytoalexin expression in a novel plant. Nature 361:153-156.

20. Harlow, A., and Lane, H. 1988. Immunoblotting. Pages 471-510 in: Antibodies: A Laboratory Manual. Cold Spring Harbor Laboratory, Cold Spring Harbor, NY.

21. Hunkapiller, M. W., Lujan, E., Ostander, F., and Hood, L. E. 1983. Methods in Enzymology. Vol. 91. C. H. W. Hirs and S. N. Timasheff, eds. Academic Press, New York.

22. Jach, G., Gornhardt, B., Mundy, J., Logemann, J., Pinsdorf, E., Leah, R., Schell, J., and Maas, C. 1995. Enhanced quantitative resistance against fungal disease by combinatorial expression of different barley antifungal proteins in transgenic tobacco. Plant J. 8:97-109.

23. Jacobs, A. K., Dry, I. B., and Robinson, S. P. 1999. Induction of different pathogenesis-related cDNAs in grapevine infected with powdery mildew and treated with ethephon. Plant Pathol. 48:325-336.

24. Jongedijk, E., Tigelaar, H., van Roeckel, J. S. C., Bres-Vloemans, S. A., Dekker, I., van den Elzen, P. J. M., Cornelissen, B. J. C., and Melchers, L. S. 1995. Synergistic activity of chitinases and $\beta-1,3$-glucanases enhances fungal resistance in transgenic tomato plants. Euphytica 85:173180.

25. Kombrink, E., and Somssich, I. E. 1997. Pathogenesis-related proteins and plant defense. Pages 107-128 in: The Mycota (Part A, Plant Relationships). G. Carrol and P. Tudzynski, eds. Springer-Verlag, Münster, Germany.

26. Laemmli, U. K. 1969. Cleavage of structural proteins during assembly of the head of bacteriophage T4. Nature 227:680-685.

27. LeGendre, N., and Matsudaire, P. 1989. Purification of proteins and peptides by SDS-PAGE. Pages 52-66 in: A Practical Guide to Protein and Peptide Purification for Microsequencing. P. T. Matsudaire, ed. Academic Press, San Diego.

28. Monteiro, S., Piçarra-Pereira, M. A., Mesquita, P. R., Loureiro, V. B., Teixeira, A. R., and Ferreira, R. B. 2001. The wide diversity of structurally similar wine proteins. J. Agric. Food Chem. 49:3999-4010.
29. Monteiro, S., Piçarra-Pereira, M. A., Tanganho, M. C., Rente, J. P., Loureiro, V. B., Teixeira, A. R., and Ferreira, R. B. 1999. Preparation of polyclonal antibodies specific for wine proteins. J. Sci. Food Agric. 79:772-778.

30. Odjakova, M., and Hadjiivanova, C. 2001. The complexity of pathogen defense in plants. Bulg. J. Plant Physiol. 27:101-109.

31. Pierpoint, W. S. 1996. The extraction of enzymes from plant tissues rich in phenolic compounds. Pages 69-80 in: Protein Purification ProtocolsMethods in Molecular Biology. Vol. 59. S. Doonan, ed. Humana Press, Totowa, NJ.

32. Punja, Z. K., and Raharjo, S. H. T. 1996. Response of transgenic cucumber and carrot plants expressing different chitinase enzymes to inoculation with fungal pathogens. Plant Dis. 80:999-1005.

33. Renault, A.-S., Deloire, A., and Bierne, J. 1996. Pathogenesis-related proteins in grapevines induced by salicylic acid and Botrytis cinerea. Vitis 35:49-52.

34. Robinson, S. P., Jacobs, A. K., and Dry, I. B. 1997. A class IV chitinase is highly expressed in grape berries during ripening. Plant Physiol. 114:771-778.

35. Robyt, J. F., and White, B. J. 1987. Biochemical Techniques. Theory and Practice. Brooks/Cole Publishing, Monterey, CA.

36. Salzman, R. A., Tikhonova, I., Bordelon, B. P., Hasegawa, P. M., and Bressan, R. A. 1998. Coordinate accumulation of antifungal proteins and hexoses constitutes a developmentally controlled defense response during fruit ripening in grape. Plant Physiol. 117:465-472.

37. Segarra, I., Lao, C., López-Tamames, E., and Torre-Boronat, M. C. 1995. Spectrophotometric methods for the analysis of polysaccharide levels in wine making products. Am. J. Enol. Vitic. 46:564-570.

38. Showalter, A. M., Bell, J. N., Cramer, C. L., Bailey, J. A., Varner, J. E., and Lamb, C. J. 1985. Accumulation of hydroxyproline rich glycoprotein mRNAs in response to fungal elicitor and infection. Proc. Natl. Acad. Sci. USA 82:6551-6555.

39. Somssich, I. E., and Hahlbrock, K. 1998. Pathogen defence in plants - a paradigm of biological complexity. Trends Plant Sci. 3:86-90.

40. Swerdlow, P. S., Finley, D., and Varshavsky, A. 1986. Enhancement of immunoblot sensitivity by heating of hydrated filters. Anal. Biochem. 156:147-153.

41. Tattersall, D. B., Heeswijck, R., and Hoj, P. B. 1997. Identification and characterization of a fruit-specific, thaumatin-like protein that accumulates at very high levels in conjunction with the onset of sugar accumulation and berry softening in grapes. Plant Physiol. 114:759-769.

42. Terakawa, T., Takaya, N., Horiuchi, H., Koike, M., and Takagi, M. 1997. A fungal chitinase gene from Rhizopus oligosporus confers antifungal activity to transgenic tobacco. Plant Cell Rep. 16:439-443.

43. van Loon, L. C. 1999. Occurrence and properties of plant pathogenesisrelated proteins. Pages 1-19 in: Pathogenesis-Related Proteins in Plants. S. K. Datta and S. Muthukrishnan, eds. CRC Press, Boca Raton, FL.

44. Weber, K., and Osborn, M. 1969. The reliability of molecular weight determinations by dodecyl-sulfate-polyacrylamide gel electrophoresis. J. Biol. Chem. 244:4406-4412.

45. Yamamoto, Y., Iketani, H., Ieki, H., Nishizawa, Y., Notsuka, K., Hibi, T., Hayashi, T., and Matsuta, N. 2000. Transgenic grapevine plants expressing a rice chitinase with enhanced resistance to fungal pathogens. Plant Cell Rep. 19:639-646.

46. Zhu, Q., Maher, E. A., Masoud, S., Dixon, R. A., and Lamb, C. J. 1994. Enhanced protection against fungal attack by constitutive co-expression of chitinase and glucanase in transgenic tobacco. BioTechniques 12: 807-812. 